\title{
Storytelling strategy to improve coherence in writing skills development
}

\section{Storytelling strategy to improve coherence in writing skills development}

Noemi Mercedes Remache Carrillo. ${ }^{1}$, Viviana Vanessa Yánez Valle. ${ }^{2}$ \& Mariela Germania Pilco Labre. ${ }^{3}$

\begin{abstract}
.
This research had as its main purpose to determine how the Storytelling strategy improves coherence in writing skills. To appraise the efficacy of this strategy, a writing pre-test and a post-test were applied to the sixth level students of the Cambridge Language Center extension of the Escuela Superior Politécnica de Chimborazo during the September 2018 - February 2019 academic period. Those exams focused on the writing part from Cambridge PET (Preliminary English Test). A guide for the teacher was designed which was used during the classroom intervention. That guide was mainly based on the three stages of the writing process: prewriting, writing itself, and review through the use of use the following techniques: narrative, visual history, problem / solution, dialogue; and, hero and enemy. The analysis and interpretation of the obtained data which came from the pre and the post-tests before and after the intervention was performed. Once the application of the proposal was accomplished, the data obtained from the pre-test and the post-test was processed by using the T-student mathematical test with the statistical software SPSS (Statistical Package for the Social Sciences). The results demonstrated that the application of the Storytelling strategy generated high interest and improvement in the students' production of written texts. Therefore, the Storytelling strategy contributes with the enhancement of students' written

1 Escuela Superior Politécnica de Chimborazo, Centro de Idiomas, Riobamba, Ecuador, noemi.carrillo@espoch.edu.ec

2 Escuela Superior Politécnica de Chimborazo, Centro de Idiomas, Riobamba, Ecuador, viviana.yanez@espoch.edu.ec

3 Unidad Educativa Riobamba, Riobamba, Ecuador, marielapilco@yahoo.com
\end{abstract}


production. Finally, it was concluded that students improved coherence in their written texts through the Storytelling strategy. Consequently, it is recommended that English teachers apply this proposal with the Storytelling strategy in their educational work to improve the development of students in their English language learning process.

Keywords: Coherence, implementation, pre-writing, , Storytelling, strategy, writing

\section{Introduction.}

English is considered a global language hence it is the language of education, technology, science, business, tourism, fashion, and media, among others. It is considered global because a number of people around the world communicate through it either as a first language or as a second language or foreign language (Crystal, 2003). According to the Common European Framework of Reference (2001) English is placed in the context of a particular setting within domains like personal, public, occupational, and/or educational. Furthermore, peoples' communicative language competence is activated by different language activities such as oral and/or written. Under these circumstances, the present research problem contextualization will be focused on macro, meso and micro contexts.

English language use is studied according to the "three circles" of English (Kachru, 1988 as cited in Crystal, 2003). The Inner circle refers to English language users who communicate with it as their primary language in countries like USA, UK, New Zealand, Australia, Canada, and Irland. Besides, the outer circle states the spread of English in non-native environments. Countries like Singapore, India, Malawi, and 50 other territories use it as their second language. They also recognize multilingual settings. Further, the expanding circle involves places like China, Japan, and Greece among other 75 countries that recognize English as an international language and is taught as a foreign language (Crystal, English as a Global Language, 2003).

Correct grammar phrases or sentences are not the only significant aspect to consider when grading essays but syntax, meaning and message clearly delivered. In addition, for teachers, it is important to be clear about providing effective feedback that helps the student notice the sections of writing that have been written well and those sections that need improvement taking into account important aspects such as critical thinking, target audience, and content (Jokic, 2017). Finally, getting the students to know exactly what is expected from their written work and giving clear guidance and examples would provide them with ideas to follow and develop their writing skills; this could be achieved by the use of Storytelling strategy.

At Languages Center "Cambridge" Extension at ESPOCH, students are struggling with English writing skills. The academic scores which are registered in the secretary's office show that students have a low level of writing skills. Besides, the researcher has applied her diagnostic test in the form of a Pre-test for this research at the beginning of the September 
2018- February 2019 academic period and the result was deficient in the writing skills part. As a result, they will not succeed in their final Cambridge International Exam. Therefore, a research is needed to help them to improve their writing skills especially because they require building up coherence in their writing productions.

Leaning about how to improve students' English language skills is very important for all the society. Carrying out this study is fundamentally important because learners at Escuela Superior Politécnica de Chimborazo need to enhance the coherence in their writing skills. It is widely known that English is considered as a global language, so students must be competent in their language performance to face global challenges. Furthermore, contributions for achieving this goal are needed in the Ecuadorian education.

As it has been explained above, students have high difficulties with writing skills, especially when they try to write with coherence. Therefore, this study is necessary. Contributing to the development of this country is a big deal nowadays. This society needs people who create and develop new technologies, and they must be written in a good way of achieving an efficient communication.

Moreover, this study is also original because teachers need to motivate students to write by using different strategies. Storytelling is the act of telling a story by connecting with the listener and/or the reader (Oxford Dictionary, 2018), and if teachers can add another purpose like writing with coherence can be innovative in class development. Furthermore, students are engaged in class and learn when classes are different.

Finally, this research is feasible for authorities at Languages Center Cambridge Extension at Escuela Superior Politécnica de Chimborazo are supporting people who contribute with the science and advancement of the institution; therefore, this investigation is widely supported for a collective benefit.

\section{Storytelling}

Storytelling is the art which helps to narrate a tale or story instead of reading it. It is said that Storytelling is one of the most ancient of art forms that involves two main elements: selection and delivery. The teacher selects adequate stories for the delivery which needs practice and preparation. Besides, it fosters emotional intelligence and encourages language learning by building vocabulary and language structures (Dujmović, 2006). Storytelling helps to foster social interaction and learning social rules (Kluger, 2017).

Serrart (2008) states Storytelling is "the use of stories or narratives as communication tools to value, share, and capitalize on the knowledge of individuals". It means that Storytelling is the picturesque description of ideas, personal experiences like life-lessons by means of narratives which summon emotions and insights. Storytelling has some advantages such as 
the combination of emotional aspects with factual concepts; the provision of a wider context where knowledge increases for meaningful sharing; and, the connection of facts with narrative structures. Furthermore, storytellers communicate naturally.

Storytelling has the same etymology as History. Yiannis (2003) states the words Story and History derive from a Greek group of words that include the word "histos" which means "web"; furthermore, "histanai" which means "to stand"; and "edenai" that means "to know well". He proposes that Storytelling is a delicate process which can be disintegrated easily; however, good stories can be valuable and have different aims such as entertaining, inspiring, educating, and convincing. Furthermore, Storytelling aims three important goals: entertaining, knowledge transferring, and warning because there is a deep connection between the writer and the people who listen or read the story (Massa, 2018).

The Storytelling strategy can be used with some techniques such as narrative technique, enemy and a hero, conflict/solution, making the story visual, surprise, and dialogue.

Narrative technique is also called as literary device which provides profound meaning for the reader and helps people who read to use imagination in order to visualize situations. Narrative technique is also understood in the context of setting, plot, theme, style, characters, and/ or voice (Warner, 2018).

Besides, writers use narrative techniques for making stories interesting to the reader because it is much more important how the story is told than what the story is about. Those techniques respond to four questions: first, who is telling the story; then, who is the writer communicating to?; how the narrator and the characters communicate to each other in the story; and, when the events happened (McIntire \& Pruzinsky, 2018).

Narrative technique has some components; therefore, it deals with the author's point of view, narration, speech, and tense. Point of view answers the following question: Who is telling the story?. Therefore, the answers can be the narrator of the story, first person, and the reader of the story, second person, or someone else, third person. The second component of this technique is narration. Narration answers the question: Who is the narrator talking to?. This question has three different answers: direct narration when the author talks to the reader, directly; frame narration is used when the narrator describes someone else's story; and, indirect narration which is used by the narrator when he or she is talking to an absent audience. The third component is speech, which answers the following question: ¿How does the narrator speak? This question can be answered with direct speech, indirect speech, and reported speech. The final component of the narrative technique is tense. Tense refers to the time the story takes place. It can be in the present, past or future tense which take the form of predictions or instructions (McIntire \& Pruzinsky, 2018). 
Storytellers need to follow some steps to produce an interesting story. First, the writer organizes information needed into a scheme. This format has a beginning where the author sets the stage. The story also needs a hard challenge to be completed. It happens in the middle of the story. And at the end of the story, the writer ends in a new reality (Malamed, 2016).

Another Storytelling technique is the dialogue technique which refers to the use of conversations among the characters which let the writer to create interesting and engaging stories. The author craves the drama when characters interact in a story (Khoury, 2018). According to Wilson (2018), stories which have dialogues seem to be real because their characters are communicating to each other. With this fact, readers can understand characters. Furthermore, dialogues can make stories very interesting and they also can make them to have faster advancement.

\section{Methodology}

The present study was based on mixed methods research modality. Mixed methods research is a methodology which is used for addressing investigation that involves collecting, analyzing, and integrating both quantitative and qualitative data (Schoonenboom \& Johnson, 2017); for instance, theoretical data was collected from the research background, the theoretical foundation of the two variables of this study, from the students' productions before and after the teacher's intervention in the classroom, and from the responses that came from the students and the teachers in the survey: so, all of them constituted the qualitative data for this research. On the other hand, after receiving the pre-and post-test, the researcher graded the students' stories and used a rubric for this purpose.

That rubric had scales of assessment that helped to obtain quantitative data. Thereafter, this quantitative data which came from the exams and the survey were analyzed with the SPSS statistical software through the Cronbach alpha, for validity and reliability; and, and the Tstudent test in order to prove the hypothesis. Furthermore, a survey was applied for both teachers and students. The integration of those kinds of data provided a better understanding of the research problem. Based upon the theory, this research modality was fundamental in the consecution of this study which was carried out with students at Cambridge Language Extension of Escuela Superior Politécnica de Chimborazo.

Qualitative research is helpful when the researcher aims to develop a theory that will be explained after the experience (Newman \& Benz, 1998); therefore, it involves discovery. Social phenomenon is an identifier of the qualitative research which is researched from the participants' point of view. Furthermore, it is useful to describe, explain, and interpret the collected data (Wiliams, 2007). Qualitative research is an effective model which lets the researcher involved in the research process (Cresswell, 2003 as cited in Wiliams, 2007). 
Qualitative research lets to observe the social phenomenon in the classroom setting to establish the research questions (Wiliams, 2007). Inductive reasoning is associated with qualitative research since it collects data through the use of narrative or verbal methods such as observations, interviews, and document analysis (Lodico, Spaulding, \& Voegtle, 2010).

On the other hand, quantitative research focuses on the hypotheses and their testing for confirming or discarding them (Newman \& Benz, 1998). Sousa, Driessnack, and Costa (2007) claim quantitative investigation adopts a strict, systematic, and objective strategy to produce and polish knowledge. This design uses deductive reasoning and generalization initially. Deductive reasoning is a process where the researcher starts with an established theory or structure, in which concepts are reduced to variables, collecting evidence to evaluate or prove if the theory is confirmed. While generalization deals with conclusions which are developed from the evidence collected through samples. They can be extended into a larger population.

Besides, this study is focused on applied research for it aims to solve practical issues (Cherry, 2018). Since writing skill is part of English teaching and learning process which impacts in students' performance, it is important to find solutions for its problems, in this case, the application of Storytelling strategy for coherence in writing productions.

The present research is centered on three main kinds for research: socio-educational research, quasi-experimental research, descriptive research, and applied research.

This study deals with socio-educational design as well because it involves language learning of students at ESPOCH as part of their knowledge background, identity, and social context (Cohen, Manion, \& Morrison, 2007). This study motivates to develop an effective intervention related to the use of Storytelling strategy for improving coherence in writing skills.

This research has a quasi-experimental design for two reasons. First, the researcher has done her investigation with two groups, the control group and experimental one. They were previously established (Lodico, Spaulding, \& Voegtle, 2010) by the Languages Center Cambridge Extension at Escuela Superior Politécnica de Chimborazo. Secondly, the researcher has given the PET Writing part as the pre-test and the post-test to both control and experimental groups. The former test was developed before the researcher's intervention and the latter was taken by the students after the researcher's intervention in a real classroom setting also called as field experimentation (Cohen, Manion, \& Morrison, 2007) rather than in a laboratory (Muijs, 2011).

The present research is also centered in a descriptive design since it aims to seek about the incidence and the values in which one or more variables are displayed. Besides, studies 
establish hypotheses (Hernández, Fernández, \& Baptista, 1997). Consequently, this study has described two variables and hypotheses as well.

This study is correlational for it attempts to describe the relationship between two variables in a determined time (Hernández, Fernández, \& Baptista, 1997). For that reason, the relationship of Storytelling strategy for coherence in writing skills has been analyzed.

This study is also focused on applied research because it aims to provide data about the applicability of teaching practices through the researcher's intervention in a class by testing hypotheses (Lodico, Spaulding, \& Voegtle, 2010); therefore, the effectiveness of the Storytelling strategy for coherence in writing skills has been proved.

The present study was developed at the Language Center Cambridge Extension at Escuela Superior Politécnica de Chimborazo. The researcher has worked with 14 English teachers and two groups of students who belonged to the experimental group and the control group. Those students were part of the Sixth level. The control group was formed by 25 students and the experimental group was formed by 26 students as the table below shows.

Table 1. Population

\begin{tabular}{lll}
\hline Groups of Students & Number of students & $\%$ \\
\hline Control & 25 & $49.02 \%$ \\
Experimental & 26 & $50.98 \%$ \\
\hline
\end{tabular}

Created by: Yanez, V. (2018)

As the present study has a quasi-experimental design because it was carried out in the classroom not in a laboratory (Cohen, Manion, \& Morrison, 2007); furthermore, the PET exam general writing part1 was applied to both control and experimental groups of students. PET exam is used because Cambridge English writing scripts are marked by trained professional examiners in a secure online marking environment. The Writing Examiners award marks using a Writing Assessment Scale which was developed with explicit reference to the Common European Framework of Reference for Languages. It covers all the levels of the Cambridge English exams and is divided into four subscales namely content, communicative achievement, organization, and language (Cambridge, 2018).

The writing part of this exam has one single question which consists in one single task that wants the students to write about any person in the community who deserves a reward because of any good action for the society. The details that students have to take into consideration are:

- write the name of the person who rewards the recognition

- describe the story what he or she did to help the community;

- and, write about what regard the writer would like to give this person. 
PET writing part exam was taken as the tool to develop the pre and post-tests. The pre-test can be observed in the Annex 3 and the post-test can be found in the Annex 4. The pre-test and the post-test had their corresponding assessment rubric which is placed in the annex 5 of this study.

The rubric is widely connected with the exam has 4 criteria related to writing development namely content, communicative achievement, organization, and language, like the main issues in the exam. Content evaluates if the written material produced by the student is relevant to the proposed task or if the learner clearly communicates the message. Communicative achievement assesses if the writer holds the reader's attention and communicates straightforward ideas. Organization refers to coherence in the written production and the way it is organized to transmit the message. Finally, language refers to the appropriate use of vocabulary. The rubric also has 6 scales of assessment from 0 which is the lowest to 5 that is the highest (Cambridge, 2018).

It was also used a survey for students and teachers that can be observed in the annex 4 and 5 . The first surveys was directed for the teachers and the annex 5 was de rubric directed to the students. The survey was constructed and validated by professionals in education from the Escuela Superior Politécnica de Chimborazo. The survey was formed by questions which aimed to determine how the Storytelling strategy enhances the coherence in students' writing skills. The survey had a kind of closed question (Chiner, 2011) type because the students had to highlight on the provided scales. Those scales were three: always, sometimes, and never.

A validated pre-test and post-test, PET exam writing part1, and a rubric were necessary to use for the collection of data about the effectiveness of Storytelling strategy to improve coherence in writing skills. The present study was conducted to 51 students who attend to Language Center Cambridge Extension at Escuela Superior Politécnica de Chimborazo. Before taking the post-test, a researcher's intervention was developed for one month. This intervention was related to class planning which aimed to apply Storytelling and writing techniques for improving coherence in students' written productions. Besides, to work with students during the intervention, a booklet containing techniques was created and used.

Furthermore, it was also necessary to pass a survey to teachers and students to classify the most effective Storytelling techniques and to determine coherence aspects for developing writing skills. The survey was validated by two professors of Escuela Superior Politécnica de Chimborazo. It was also validated with Cronbach alpha through the statistical software SPSS (Statistic package for Social Sciences) as table 6 shows below. 
Table 2. Survey validity test

\begin{tabular}{ccc}
\hline \multicolumn{3}{c}{ Validity test } \\
& \\
\hline Cronbach alpha & Cronbach Alpha based in & N. of elements \\
& standardized elements & \\
0,712 & 0,672 & 10 \\
\hline
\end{tabular}

Created by: Yánez, V. (2018)

Once the instruments were applied it was necessary to:

- Tabulate the collected data

- Analyze and interpret the results

\section{Analysis and Interpretation.}

\section{Pre and post-tests results Preliminary English Test: Writing}

As it has been mentioned before, two groups of students were part of this study, the control group and the experimental one. The former had a population of 25 students and the latter was formed by 26 students. Furthermore, two tests were given to all the students before (pretest) and after (post-test) the researchers' intervention to both the control and the experimental groups. Consequently with the data obtained and the analysis were performed as it is detailed below:

\section{Control group - Pre-test}

Table 3. Pre-test Control Group

\begin{tabular}{lc}
\hline \multicolumn{1}{c}{ Writing Pre-test } & \\
Criteria & Average \\
\hline Content & 1,6 \\
Communicative Achievement & 1,24 \\
& \\
Organization & 1,6 \\
Language & 1,4 \\
Expected Average & 5,00 \\
\hline
\end{tabular}

Source: Pre-test Control group

Created by: Yanez, V. (2018) 


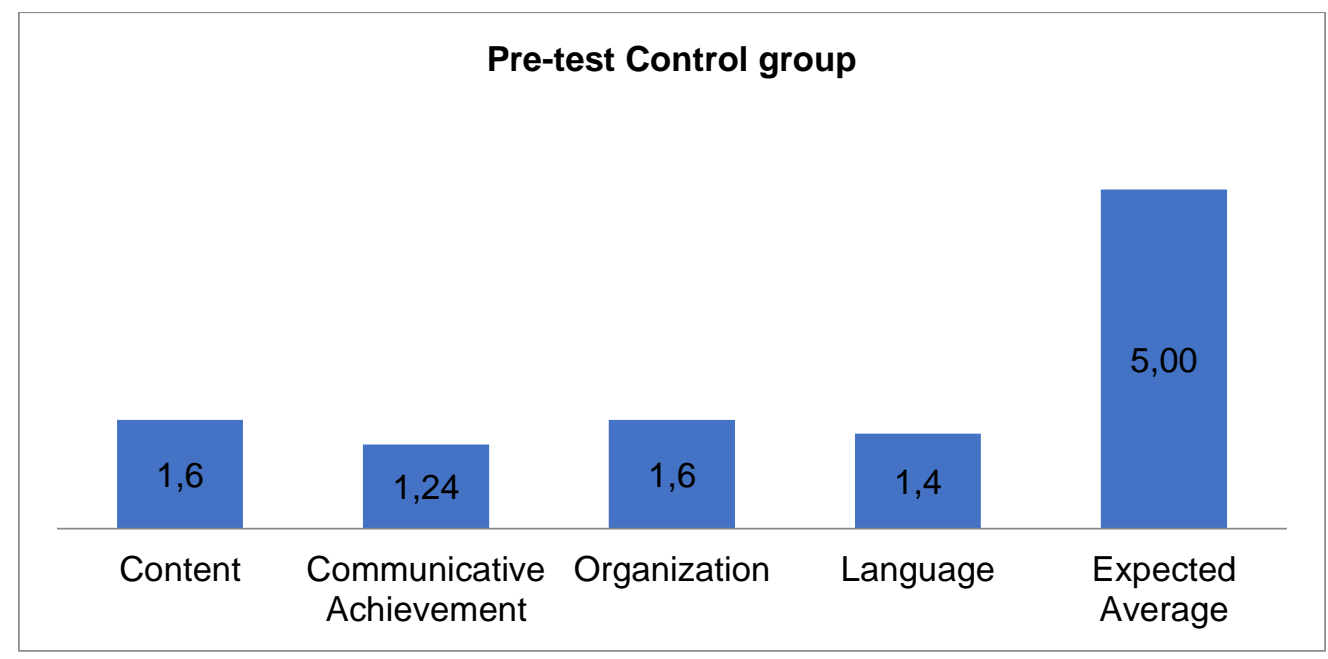

Figure 1. Pre-test Control Group

Created by: Yanez, V. (2018)

The assessment rubric had four main criteria such as content, communicative achievement, organization, and language as detailed in Annex 5 of the current study.

It is clearly stated that control group started with 1,6 in content, 1,24 in communicative achievement, 1,6 in the organization, and 1,4 in language. It is also important to mention that the expected average was 5 .

\section{Control group - Post-test}

Table 4. Post-test Control group

\section{Writing Post-test}

\begin{tabular}{lc} 
& Average \\
\hline Content & 2,12 \\
Communicative Achievement & 2,08 \\
& \\
Organization & 1,56 \\
Language & 2,00 \\
Expected Average & 5,00 \\
\hline
\end{tabular}

Created by: Yánez, V. (2018) 


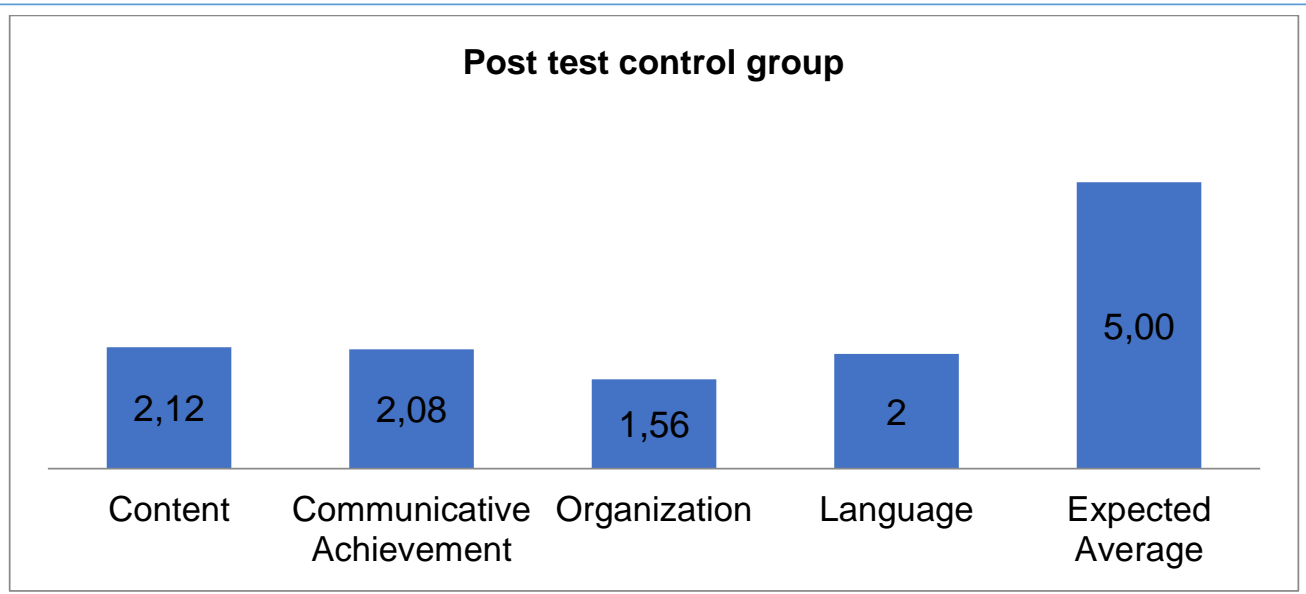

Figure 2. Post-test control group

Created by: Yánez, V. (2018)

On the contrary, the results in the post-test for the control group are 2,12 in content, 2,08 in communicative achievement, 1,56 in organization, and 2,00 in language.

\section{Experimental group - Pre-test}

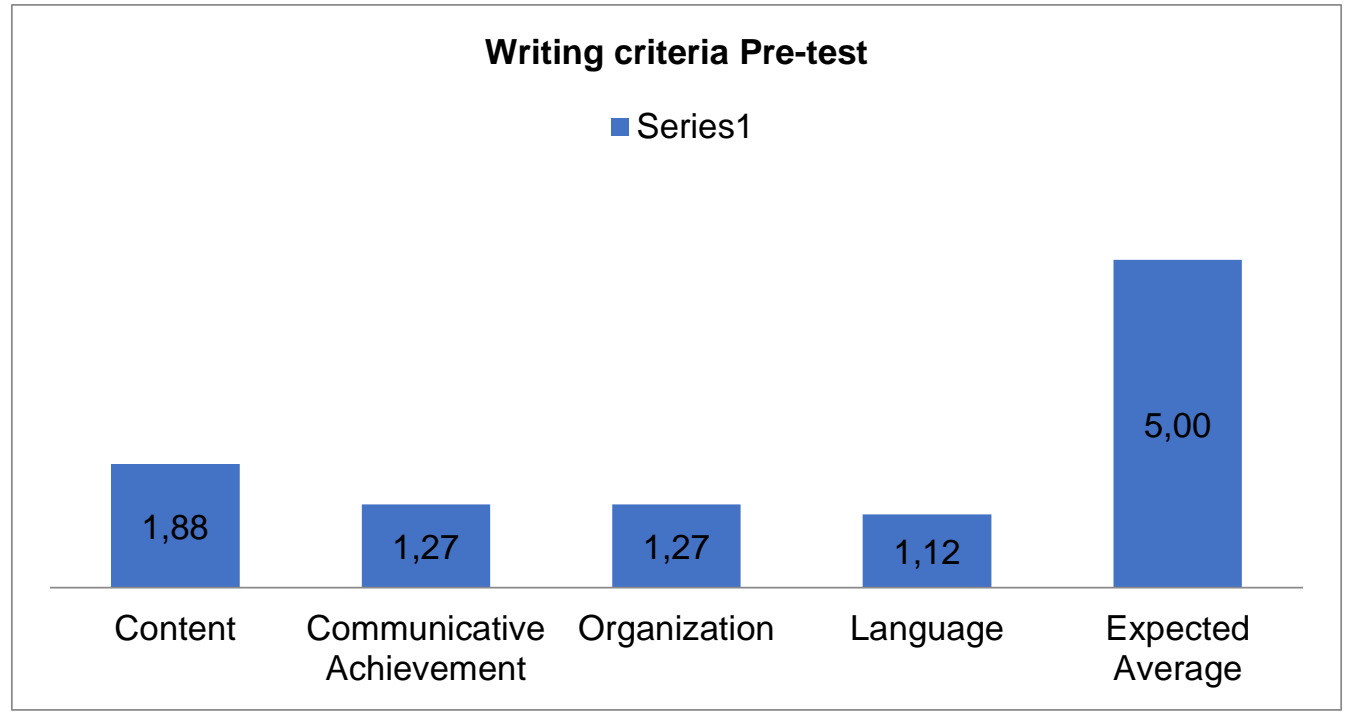

Figure 3. Pre-test experimental group

Created by: Yánez, V. (2018)

The experimental group obtained the following average in the corresponding criteria: in content 1,88 , in the communicative achievement 1,27 , in the organization 1,27 ; and, 1,12 in language. 


\section{Experimental group - Post-test}

Table 6. Post-test experimental group

\begin{tabular}{lc}
\hline \multicolumn{2}{c}{ Writing Criteria } \\
\hline Post - Test & Average \\
Content & 3,15 \\
Communicative Achievement & 3,15 \\
Organization & 3,92 \\
Language & 3,00 \\
Expected Average & 5,00 \\
\hline
\end{tabular}

Created by: Yánez, V. (2018)

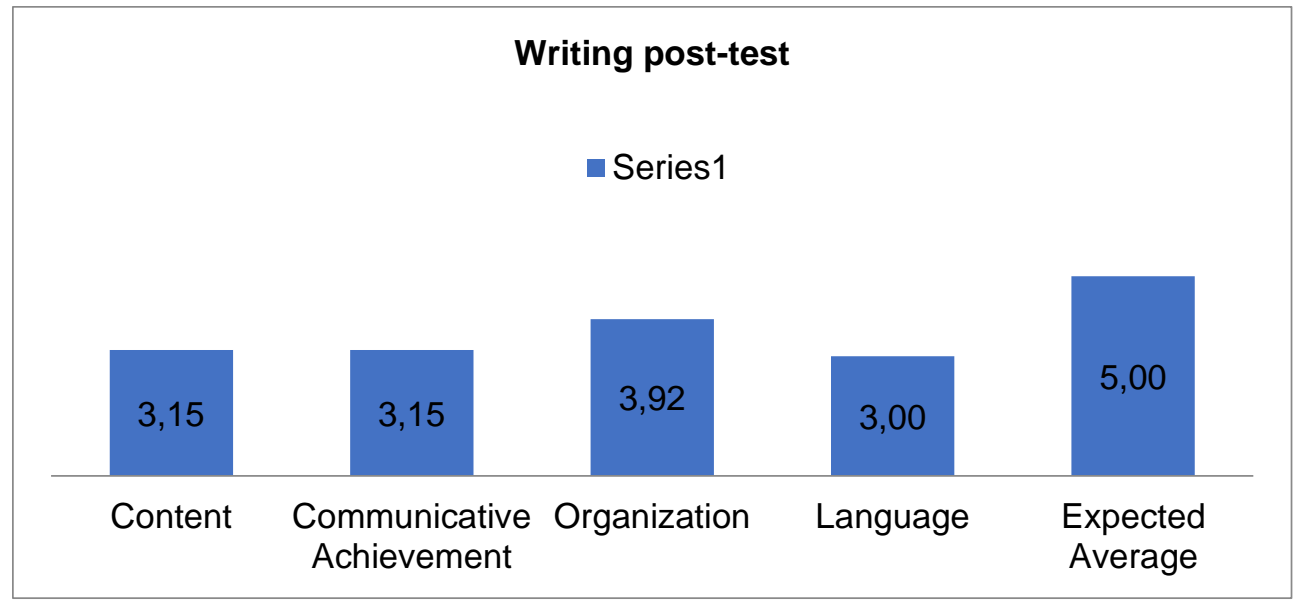

Figure 3. Post-test experimental group

Created by: Yánez, V. (2018)

On the other hand, the post-test results which belong to the experimental group are content 3,15 , communicative achievement 3,15, organization 3,92, and language 3 .

\section{Hypothesis verification}

For the hypothesis verification, it is important to remark about the alternative hypothesis and the null hypothesis which were set in chapter two.

H1. A researcher's intervention through the use of Storytelling strategy improves coherence in writing skills.

H0. A researcher's intervention through the use of Storytelling strategy does not improve coherence in writing skills.

This study was carried out at Cambridge Languages Center in the Escuela Superior Politécnica de Chimborazo with students of 6th level during one month. The hypothesis verification was performed with SPSS statistical software and with the T- student test. 


\section{Reliability test}

Table 7. Reliability test

\begin{tabular}{llcc}
\hline \multicolumn{3}{c}{ Summary of cases processing } \\
& & $\mathrm{N}$ & $\%$ \\
\hline \multirow{3}{*}{ Cases } & Valid & 51 & $100 \%$ \\
& Excluded & 0 & $0,0 \%$ \\
& Total & 51 & 100,0 \\
\hline
\end{tabular}

Created by: Yánez, V. (2018)

For this study, 51 valid cases were treated divided into two main groups. The first group is called the Control group with 25 valid cases and the second one which is called the experimental group with 26 valid cases.

Table 8. Statistics of reliability

\begin{tabular}{cc}
\hline \multicolumn{2}{c}{ Statistics of reliability } \\
\hline Cronbach Alfa & N of elements \\
0,259 & 2 \\
\hline \multicolumn{3}{c}{ Created by: Yánez, V. (2018) }
\end{tabular}

Cronbach Alpha determines a reliability of 0,259 which is a positive result; it means that the results and the tests are reliable in with two elements or Control and Experimental groups. Normal distribution test

Table 9. Normal distribution test. Control group: pre-test

\begin{tabular}{llr}
\hline \multicolumn{3}{c}{ CONTROL GROUP } \\
\multicolumn{3}{c}{ Kolmogorov-Smirnov test for one data $^{\mathrm{a}}$} \\
& & $\mathrm{N}$ \\
PRE-TEST \\
Normal parameters ${ }^{\mathrm{b}, \mathrm{c}}$ & Mean & 25 \\
& Std. Deviation & 5,8400 \\
Most Extreme & Absolute & 2,47790 \\
Differences & Positive & 0,313 \\
& Negative & 0,313 \\
Test Statistic & & $-0,229$ \\
Asip.Sig. (2 tailed) & & 0,230 \\
\hline
\end{tabular}

Created by: Yánez, V. (2018) 
Table 10. Normal distribution test. Experimental group: pre-test

\begin{tabular}{|c|c|c|}
\hline \multicolumn{3}{|c|}{ EXPERIMENTAL GROUP } \\
\hline \multicolumn{3}{|c|}{ Kolmogorov-Smirnov test for one data ${ }^{a}$} \\
\hline & & PRE-TEST \\
\hline \multicolumn{2}{|c|}{$\mathrm{N}$} & 26 \\
\hline \multirow[t]{2}{*}{ Normal parameters ${ }^{b, c}$} & Mean & 5,5385 \\
\hline & Std. Deviation & 1,67883 \\
\hline Most Extreme & Absolute & ,241 \\
\hline \multirow[t]{2}{*}{ Differences } & Positive & ,241 \\
\hline & Negative &,- 180 \\
\hline \multicolumn{2}{|c|}{ Test Statistic } & ,230 \\
\hline \multicolumn{2}{|c|}{ Asip.Sig. (2 tailed) } &, $000^{d}$ \\
\hline
\end{tabular}

Created by: Yánez, V. (2018)

According to the information above, the Kolmogorov-Smirnov Test for one data shows that the distribution of the population is normal in both the control group and the experimental group. The Asip. Sig is $\mathbf{< 0 , 0 0 5}$; therefore, there is enough evidence to affirm that the data come from a normal distribution.

These results let the researcher continue with the T-student test to compare population means.

T - Student test to compare population means

Table 11. T-student to compare population means

\begin{tabular}{cccccc}
\hline \multicolumn{5}{c}{ Group statistics } \\
& GROUP & N & Mean & $\begin{array}{c}\text { Standard } \\
\text { Deviation }\end{array}$ & $\begin{array}{c}\text { Standard } \\
\text { error mean } \\
\end{array}$ \\
& Control & 25 & 5,8400 & 2,47790 &, 49558 \\
PRE- & Experimental & 26 & 5,5385 & 1,67883 &, 32925 \\
TEST & & & & & \\
\hline
\end{tabular}

Created by: Yanez, V. (2018) 
Table 12. Levene test for Equality

\begin{tabular}{|c|c|c|c|c|c|c|c|c|c|c|}
\hline \multicolumn{11}{|c|}{ Independent samples T-Test } \\
\hline & & \multicolumn{2}{|c|}{$\begin{array}{l}\text { Levene test } \\
\text { for equality }\end{array}$} & \multicolumn{7}{|c|}{ T-test for equality of means } \\
\hline & & \multirow[b]{2}{*}{$\mathrm{F}$} & \multirow[b]{2}{*}{ Sig. } & \multirow[b]{2}{*}{$\mathrm{t}$} & \multirow[b]{2}{*}{ gl } & \multirow{2}{*}{$\begin{array}{l}\text { Sig.(t } \\
\text { wo- } \\
\text { tailed) }\end{array}$} & \multirow{2}{*}{$\begin{array}{c}\text { Mean } \\
\text { Differen } \\
\text { ce } \\
\end{array}$} & \multirow{2}{*}{$\begin{array}{l}\text { Standard } \\
\text { Error } \\
\text { Difference } \\
\end{array}$} & \multicolumn{2}{|c|}{$\begin{array}{c}95 \% \text { Confidence } \\
\text { Interval of the } \\
\text { Difference }\end{array}$} \\
\hline & & & & & & & & & Inferior & Superior \\
\hline \multirow[t]{2}{*}{$\begin{array}{l}\text { PRE- } \\
\text { TEST }\end{array}$} & $\begin{array}{l}\text { Equal } \\
\text { variances } \\
\text { assumed }\end{array}$ & 1,855 & 0,179 & 0,511 & 49 & 0,612 & 0,30154 & 0,59058 & $-0,88528$ & 1,48836 \\
\hline & $\begin{array}{l}\text { Equal } \\
\text { variances } \\
\text { not assumed }\end{array}$ & & & 0,507 & 42,006 & 0,615 & 0,30154 & ,59498 & $-0,89918$ & 1,50225 \\
\hline
\end{tabular}

Created by: Yanez, V. (2018)

The Levene test for equality of variances which is displayed above, it is clearly assumed that the Sig. is > 0.05; in the table above, it is 0.179 . Hence, equal variances are assumed.

Moreover, the T-test for equality of means demonstrates that the Sig. is 0,179 which is > 0.05; therefore, there are no significant differences between the mean in the control group and the mean in the Experimental group with a $95 \%$ of confidence.

\section{T-TEST}

Finally, T-test aims to prove whether there is an important difference between the means of both the control and the experimental groups in the Post-test or not. This idea is set for the alternative hypothesis in the current study deals with a researcher's intervention through the use of Storytelling strategy improves coherence in writing skills.

The researcher has accomplished an intervention through Storytelling strategy to improve coherence in writing skills, it is needed to see if the intervention has fulfilled its goals or not. The intended hypothesis is:

$$
\mu 1 \neq \mu 2
$$

The formula shown above implies that the means in the Control group, G1, is not the same as the means in the Experimental group, G2, for the post-test. 
Table 13. T-Test. group statistics. Post- test

\begin{tabular}{cccccc}
\hline & \multicolumn{5}{c}{ Group statistics } \\
\hline & GROUP & $\mathrm{N}$ & Mean & $\begin{array}{c}\text { Standard } \\
\text { Deviation }\end{array}$ & $\begin{array}{c}\text { Standard } \\
\text { error mean }\end{array}$ \\
POST- & Control & 25 & 7,7600 & 2,38537 &, 47707 \\
TEST & Experimental & 26 & 13,230 & 3,19133 &, 62587 \\
& & & 8 & & \\
\hline
\end{tabular}

Created by: Yanez, V. (2018)

Table 14. Independent sample T-test. Posttest

\begin{tabular}{|c|c|c|c|c|c|c|c|c|c|c|}
\hline \multicolumn{11}{|c|}{ Independent samples T-test } \\
\hline & & \multicolumn{2}{|c|}{$\begin{array}{l}\text { Levene test } \\
\text { for equality }\end{array}$} & \multicolumn{7}{|c|}{ T-test for equality of means } \\
\hline & & \multirow[t]{2}{*}{$\mathrm{F}$} & \multirow[t]{2}{*}{ Sig } & \multirow[t]{2}{*}{$\mathrm{t}$} & \multirow[t]{2}{*}{ gl } & \multirow[t]{2}{*}{$\begin{array}{l}\text { Sig.(two } \\
\text {-tailed) }\end{array}$} & \multirow[t]{2}{*}{$\begin{array}{l}\text { Mean } \\
\text { Differe } \\
\text { nce }\end{array}$} & \multirow{2}{*}{$\begin{array}{l}\text { Stan } \\
\text { dard } \\
\text { Error } \\
\text { Differ } \\
\text { ence }\end{array}$} & \multicolumn{2}{|c|}{$\begin{array}{l}\text { 95\% Confidence } \\
\text { Interval of the } \\
\text { Difference }\end{array}$} \\
\hline & & & & & & & & & Inferior & $\begin{array}{l}\text { Superi } \\
\text { or }\end{array}$ \\
\hline \multirow[t]{2}{*}{$\begin{array}{l}\text { POST- } \\
\text { TEST }\end{array}$} & $\begin{array}{l}\text { Equal } \\
\text { variances } \\
\text { assumed }\end{array}$ & 2,457 & 0,123 & $-6,912$ & 49 & 0,000 & $-5,47077$ & $\begin{array}{l}0,7914 \\
4\end{array}$ & $-7,06122$ & $-3,88032$ \\
\hline & $\begin{array}{l}\text { Equal } \\
\text { variances } \\
\text { not } \\
\text { assummed }\end{array}$ & & & $-6,952$ & 46,233 & 0,000 & $-5,47077$ & ,78697 & $-7,05463$ & $-3,88690$ \\
\hline
\end{tabular}

Created by: Yanez, V. (2018)

The Levene test for equality shows the sig. is $>0.05$ that is 0.123 . It means that equal variances are assumed.

Furthermore, with the $95 \%$ of confidence, it is concluded that there is a high difference between the means of the $\mu 1$ with respect to $\mu 2$. G1 or Control group had a final mean of 7.7600 which is lower than the result of the G2 or Experimental group that obtained a final mean of 13,2308 .

Therefore, hypothesis 1 is accepted and hypothesis 0 is rejected. Further, the researcher's work in class with the proposal "Storytelling strategy to improve coherence in writing skills" handbook had a positive impact in the students of the 
Sixth level at Cambridge Languages Center in Escuela Superior Politécnica de Chimborazo.

\section{Conclusions}

- It was determined that Storytelling strategy highly helped to enhance coherence in writing skills; therefore the alternative hypothesis which stated Storytelling strategy enhances coherence in writing skills development was accepted. It was achieved through a teachers' intervention in the classroom, in this way, coherence was enhanced on students' writing skills through the Storytelling strategy because it is an important part of language development.

- The effects of Storytelling in the written process were positive since the total population of teachers who participated in this study show awareness of the use of Storytelling strategy to improve coherence in writing skills. Based on the results of the T-test with a reliability result; it was determined that the use of the Storytelling strategy enhances coherence in writing skills of students at the sixth level of Language Center Cambridge Extension at Escuela Superior Politécnica de Chimborazo. Both students and teachers consider Storytelling strategy as an important resource to enhance their writing skills. The data obtained from the pretest and the posttests were analyzed and the posttest results show the high improvement in the experimental group against the control which stayed in the same rate. It is concluded that alternative hypothesis is accepted; on the contrast, there is enough evidence for rejecting the null hypothesis. Therefore, the Storytelling strategy has positive effects to improve coherence in writing skills.

- The most effective Storytelling techniques for improving coherence in the development of writing skills were classified and applied during the class intervention which carried positive results in students' language progress. Both students and teachers agree that Storytelling techniques which are combined with the writing process stages help in the enhancement of coherence in writing skills. The researcher provided interesting handbook about Storytelling strategy.

\section{Referencias bibliográficas.}

Cambridge Dictionary. (2018). Cambridge Dictionary. Retrieved 2018, from https://dictionary.cambridge.org/es/diccionario/ingles/vowel

Cherry, K. (2018). What is Applied Research. Retrieved July 10, 2018, from Very well mind: https://www.verywellmind.com/what-is-applied-research-2794820

Cohen, L., Manion, L., \& Morrison, K. (2007). Research Methods in Education. New York: Routledge Taylor \& Francis Group.

Crystal, D. (2003). English as a Global Language. New York: Cambridge University Press. 
Dujmović, M. (2006). Hrcak. Retrieved May 20, 2018, from Story telling: https://hrcak.srce.hr/index.php?id_clanak_jezik=17682\&show=clanak

Hernández, R., Fernández, C., \& Baptista, P. (1997). Metodología de la Investigación. Mexico: McGRAW - Hill Interamericana de México.

Jokic, A. (2017). Evaluation of Writing Assignment. European Journal of Multidisciplinary studies, 221-224.

Khoury, P. (2018). 4 Storytelling Techniques From My 3 Favorite TED Talks. Retrieved July 19, 2018, from Magnetic: https://magneticspeaking.com/4-storytelling-techniques-from-my-3favorite-ted-talks/

Kluger, J. (2017). TIME. Retrieved June 10, 2018, from How Telling Stories Makes Us Human: http://time.com/5043166/storytelling-evolution/

Lodico, M., Spaulding, D., \& Voegtle, K. (2010). Methods in Educational Research. Retrieved July 10, 2018, from Google Scholar:

https://books.google.es/books?hl=es\&lr=\&id=Qs1CAwAAQBAJ\&oi=fnd\&pg=PA19\&dq= socio+educational+research\&ots=EDFubL855V\&sig=8BA_NHukSmJynQDJxwo-

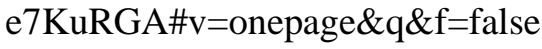

Malamed, C. (2016). The eLearning Coach. Retrieved June 15, 2018, from Why you need to use Storytelling for learning: http://theelearningcoach.com/elearning2-0/why-you-need-to-usestorytelling-for-learning/

Massa, K. (2018). Yale-New Haven Teachers Institute. Retrieved May 20, 2018, from Storytelling as a Strategy to Increase Oral Language Proficiency of Second Language Learners: http://teachersinstitute.yale.edu/curriculum/units/2008/2/08.02.01.x.html

McIntire, D., \& Pruzinsky, T. (2018). English A: Language \& Literature . Retrieved May 20, 2018, from In Thinking: https://www.thinkib.net/englishalanglit/page/10277/narrative-technique

Newman, I., \& Benz, C. (1998). Google Scholar. Retrieved July 4, 2018, from Qualitativequantitative Research Methodology: Exploring the Interactive Continuum: https://books.google.com.ec/books?hl=es\&lr=\&id=xumf1ABFz8cC\&oi=fnd\&pg=PR9\&dq =qualitative+and+quantitative+research\&ots=NF0vz-

HPWF\&sig=zdIqWHOHIQCDh2vz_C2fI2lVSZM\#v=onepage \&q=qualitative $\% 20$ and $\% 20 \mathrm{q}$ uantitative $\% 20$ research $\& \mathrm{f}=$ false

Oxford Dictionary. (2018). Retrieved April 20, 2018, from https://en.oxforddictionaries.com/definition/storytelling

Schoonenboom, J., \& Johnson, B. (2017). How to Construct a Mixed Methods Research Design. Retrieved from https://www.ncbi.nlm.nih.gov/pmc/articles/PMC5602001/

Sousa, V., Driessnack, M., \& Costa, I. (2007). Revisión de Diseños de investigación resaltantes para enfermería. Parte 1: diseños de investigación cuantitativa. Retrieved July 10, 2018, 
from SciElo: http://www.scielo.br/scielo.php?pid=S0104$11692007000300022 \&$ script=sci_arttext\&tlng=es

Warner, C. (2018). Study. com. Retrieved May 20, 2018, from Narative Techniques: https://study.com/academy/lesson/narrative-techniques-in-writing-definition-typesexamples.html

Wiliams, C. (2007). Research Methods. Journal of Business \& Economic Research, 65-72. 
Para citar el artículo indexado.

Remache Carrillo, N., Yánez Valle, V., \& Remache Carrillo, N. (2019). Storytelling strategy to improve coherence in writing skills development. Explorador Digital, 3(3.1), 123-142. https://doi.org/10.33262/exploradordigital.v3i3.1.873

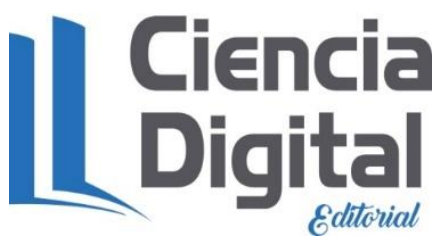

El artículo que se publica es de exclusiva responsabilidad de los autores y no necesariamente reflejan el pensamiento de la Revista Explorador Digital.

El articulo queda en propiedad de la revista y, por tanto, su publicación parcial y/o total en otro medio tiene que ser autorizado por el director o editor de la Revista Explorador

Digital.
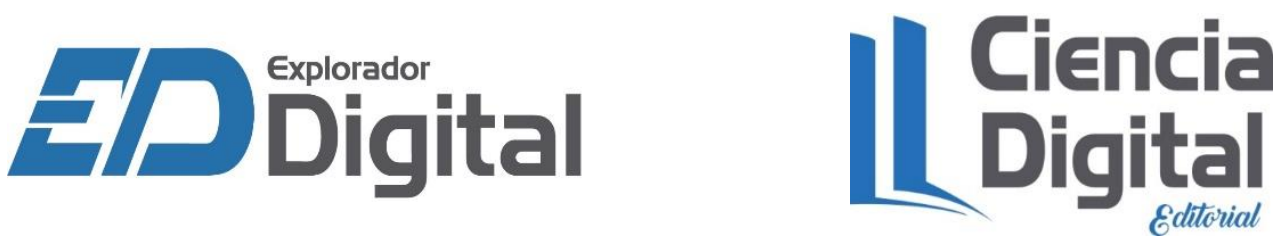